研究資料

\title{
野球オーバーハンド投球における上肢・上肢帯筋活動の表面筋電図分析
}

\author{
斎藤 健治 ${ }^{1)}$ 松尾 知之 ${ }^{2)}$ 宮崎 光次 ${ }^{3)}$
}

\section{Analysis of surface electromyogram of muscle activity in the upper limb and shoulder girdle during overhand baseball pitching}

\author{
Kenji Saitou ${ }^{1}$, Tomoyuki Matsuo ${ }^{2}$ and Mitsuji Miyazaki ${ }^{3}$
}

\begin{abstract}
In order to investigate muscle activity during overhand baseball pitching, surface EMG analysis of muscles in the shoulder girdle and upper limb was performed. The subjects were two college baseball players. Surface EMG was recorded from 25 portions of 16 muscles: the long and short head of the biceps brachii, the coracobrachialis, the brachialis, the lateral, medial and long head of the triceps brachii, the anterior, middle and posterior deltoid, the sternocostalis of the pectoralis major, the latissimus dorsi, the upper, middle and lower trapezius, three portions of the serratus anterior, the pronator teres, the flexor carpi radialis, the flexor carpi ulnalis, the extensor carpi radialis, the extensor digitorum, the extensor carpi ulnalis, and the brachioradialis. After rectifying the surface EMGs, their linear envelopes were extracted with a digital low-pass filter. The duration, timing and similarity of these muscle activities before and after ball-release were analyzed quantitatively through auto-correlation and cross-correlation analysis of the envelopes. The biceps and the brachialis were activated in the cocking phase and follow-through phase, and played a role in preparing for acceleration and deceleration in each phase. The triceps was activated in the acceleration phase and elbow joint extension, and contributed to the increase of ball speed by minimizing the moment of inertia about the longitudinal axis of the upper limb. The coracobrachialis was activated from the cocking phase until ball-release, and contributed to the horizontal extension of the shoulder joint. The latissimus dorsi and the pectoralis major were activated in the acceleration phase, and the duration of their activity was shorter than that of the other muscles. The activities of the trapezius and the serratus anterior differed between the two subjects. These activities in one subject were simultaneous in the acceleration phase, and those in the other were separate in the cocking phase.
\end{abstract}

1) 佐賀大学理工学部都市工学科

于 840-8502 佐賀県佐賀市本庄町 1

2) 大阪大学大学院医学系研究科

干 560-0043 大阪府豊中市待兼山町 1-17

3) 桜美林大学文学部健康心理学科

干 194-0294 東京都町田市常盤町 3758

連絡先 斎藤健治
1. Department of Civil Engineering, Faculty of Science and Engineering, Saga University

1 Honjo, Saga, 840-8502

2. Graduate School of Medicine, Osaka University 1-17 Machikaneyama, Toyonaka, Osaka, 560-0043

3. Department of Psychology, Health \& Sport Science, Obirin University

3758 Tokiwa, Machida, Tokyo, 194-0294

Corresponding authorssaiken@cc.saga-u.ac.jp 
These activities probably represent differences in the control of scapula motion during pitching. The peak activities of the forearm muscles were concentrated in the ball-release phase, and the duration of activity was longer in the extensor muscles than in the flexor muscles. This type of correlation analysis is useful for extracting information about muscle activity during baseball pitching.

\section{Key words : Multichannel Surface EMG, Pattern of Muscle Activity, Auto Correlation Function, Cross Correlation Function}

(Japan J. Phys. Educ. Hlth. Sport Sci. 51: 351-365, May, 2006)

\section{キーワード：多チャンネル表面筋電図，筋活動パ ターン, 自己相関関数, 相互相関関 数}

\section{Iはじめに}

野球の投球動作分析を目的とした表面筋電図学 研究は, 古くから行われているものの（豊島ほか, 1971 ; 風井ほか, 1976 ; Gowan et al., 1987 ; Bradley and Tibone, 1991 ; DiGiovine et al., 1992 ; 平野・青木，1998；斎藤ほか，2001a）， その数は決して多くない. その大きな理由は，筋 電図データと関節運動との対応関係の曖昧さにあ ると考えられる。つまり，筋電図波形には筋収縮 タイプや筋収縮速度が明確に反映されないため, 関節運動と一対一に対応させにくいという久点が 内在する.そして, 個々の関節運動との対応がと れたとしても，筋電図データから部位間の活動関 係をもとに，全体の動作を再現するのは困難であ る.さらに現行では，同時に多数の部位から筋電 図を導出する場合, 導出部位数に比例して実験遂 行上の困難度が増大し，それに比例してパフォー マンスの現実味が失われる可能性もある.例えば, 野球の投球動作のような短時間, 高速の運動では, 活動の on と off の筋電図パターンから実際の投球 動作をイメージしたり，運動を再現したりするこ とは，分析者自身が投球動作に熟練していなけれ ば非常に困難である.また, 多くの電極を貼付し て実験を行うことは，パフォーマンスの低下を招 きかねない。

一方，筋活動を筋負担，あるいは関節負担の一 つの指標と捉え, 障害予防の観点から表面筋電図
分析を試みた研究も見られる（Hang，1983； Jobe et al., 1983, 1984 ; Sisto et al., 1987 ; Glousman et al., 1988 ; Werner et al., 1993). 野球投球では，障害部位の大半が肩関節と时関節 に集中するため，それら，個々の関節を対象とす れば，分析対象数（関節，筋）が減る上に，関節 肢位や関節運動と筋活動の大小や筋収縮の夕イ プ，筋収縮スピードなどとの対応関係をより明確 に捉えやすくなる。そして，この場合，種々の不 確定要素が少なくなる分, 筋電図学的手法は動作 分析の場合のそれより有効性が高くなると考えら れる。

このような，分析上の事情を内包しながらも， 運動中の筋活動を直接計測する手法は筋電図法以 外には見あたらず，運動学・力学的にも重要な情 報を提供する手法であることに代わりはない。し たがって，画像分析を中心としたバイオメカニク 又的研究 (Sakurai et al., 1993 ; 宮西ほか, 1996 ; Barrentine et al., 1998 ; 高橋ほか, 2000 ; Matsuo et al., 2002） が投球動作分析の 主流となった現在でも, 運動学的・力学的情報を 補足する筋活動に関する定量的情報を提供するこ との意義は大きい.

本研究の目的は, 投球動作（オーバーハンド投 球）における上肢・上肢帯筋 25 部位の筋活動を 分析することであった。そのために，従来のよう な定性的分析に加え，相関分析による定量的分析 を試みた。相関分析では，筋活動の持続性や筋活 動の活動夕イミング，類似性といった活動配列や 活動部位間関係を定量的に捉えることができた。 


\section{II 方法}

\section{1. 被験者および実験試技}

被験者は, 野球経験 8 年および 10 年の大学野 球部に所属する投手 2 名であった。被験者に，十 分なウォーミングアップの後，室内に設置した防 球ネットに向かってオーバーハンドで全力投球を 行わせた。ネットまでの距離は約 $5 \mathrm{~m}$ であった。 試技は速球の全力投球であり，1セット（後述） につき 5 球の投球で合計 20 球であった。投球ス ピードはスピードガン（PSK Professional, トー アスポーツマシン社製）を用いてネット後方から 測定した。また，側方から高速度カメラ （HSV200，NAC社製）を用いて毎秒 200 コマ, シャッタースピード 1000 分の 1 秒で投球動作の 撮影を行った.

\section{2. 表面筋電図計測}

被験筋は，表 1 に示すように，上肢帯および上 肢の 16 筋 25 部位であった。表面筋電図は, 検出 面の直径が $3 \mathrm{~mm}$ の小型生体電極（日本光電社製） を用いて電極間隔 $20 \mathrm{~mm}$ で双極に導出し，テレ メー夕（日本光電社製，WEB-5000）を用いて時 定数 $0.03 \mathrm{~s}$ で増幅した。一度に計測できるのは 8 チャンネルであったため, 表 1 に示すように 4 セ ットに分けて表面筋電図計測を行った。また，試 技の再現性をモニ夕するために，4セットとも上 腕二頭笳長頭の筋電図を導出した。電極位置は,
神経支配帯分布の特徴がわかっている筋について は，それを避けるように決定した（Saitou et al., 2000)。電極貼付に当たっては，貼付位置の表皮 角質を針で一部剥離し，接触抵抗を低減した。両 被験者ともに，基準值を設定するために，実験後， 徒手負荷による最大随意等尺性収縮 (MVC) 時 の表面筋電図を記録した。導出，増幅した信号は， サンプリング周波数 $1 \mathrm{kHz}$, 精度 $12 \mathrm{bit}$, サンプル 長 $3 \mathrm{~s}$ で $\mathrm{A} / \mathrm{D}$ 変換し，パーソナルコンピュータに 取り込んだ。

\section{3. ボールリリース時刻の検出}

斎藤ほか（2002）の方法を用いて，ボールリリ ース（以下，リリース）時刻の検出を行った。す なわち，導通テープを被験者の人差し指と中指の 指先（先端から約 $5 \mathrm{~mm} ）$ およびボールに貼り付 け，指のテープはケーブルを介して電源ボックス に接続した。そして被験者がボールを握ることに より onに，指先がボールから離れることにより off になる回路を作った. 投球時, どちらか一方 の指が離れることにより回路が off になった時点 をリリース時刻とした。

\section{4. 信号処理および分析}

計測した表面筋電図は，生波形を全波整流した 後，4次のバタワース型ディジタル低域通過フィ ルタにより $30 \mathrm{~Hz}$ 以上の成分をカットして包絡線 を求めた。この際，前向きおよび後向きのフィル 夕処理を行い，フィルタリングによる位相ずれを

表 1 被験筋の一覧. 8 チャンネルのテレメータ式筋電計を用いて, 4 セットに分けて, 計 25 の部位から表面筋電図を導出した。上腕二頭筋長頭は全てのセットで導出し, 再現性の指標とした。 ×は空のチャンネルあるいは非採用のチャンネル.

\begin{tabular}{cccc}
\hline 1 & 2 & 3 & 4 \\
\hline 上腕二頭筋長頭 & 三角筋前部 & 僧帽筋上部 & 尺側手根屈筋 \\
上腕二頭筋短頭 & 三角筋中部 & 僧帽筋中部 & 橈側手根屈筋 \\
烏口腕筋 & 三角筋後部 & 僧帽筋下部 & 円回内筋 \\
上腕三頭筋長頭 & 大胸筋胸肋部 & 前鋸筋 1 ( I 肋骨 $)$ & 指伸筋 \\
上腕三頭筋外側頭 & 広背筋 & 前鋸筋 2 ( V 肋骨 $)$ & 橈側手根伸筋 \\
上腕三頭筋内側頭 & $\times$ & 前鋸筋 3 (VI肋骨 $)$ & 尺側手根伸筋 \\
上腕筋 & $\times$ & $\times$ & 腕橈骨筋 \\
$\times$ & 上腕二頭筋長頭 & 上腕二頭筋長頭 & 上腕二頭筋長頭 \\
\hline
\end{tabular}


修正した。さらに， $\mathrm{MVC}$ 時の包絡線平均值を用 いて基準化（\% MVC化）し，リリース前 $300 \mathrm{~ms}$ ーリリース後 $200 \mathrm{~ms}$ の 500ms（=T）間の信号を 分析対象として抽出した。そして, 式（1）の自 己相関関数（時間差 $\tau$ の関数）を，抽出した個々 の包絡線波形について求めた（日野，1977）.

$$
A C(\tau)=\frac{1}{T} \int_{-T / 2}^{T / 2} x(t) x(t+\tau) d t
$$

ここで，自己相関関数 $A C （ \tau)$ は,

$$
A C E(\tau)=\exp \left(\frac{-\tau}{p}\right)
$$

により包絡線近似できるため，この関数の $p$,

$$
p=\int_{0}^{T / 2}|A C(\tau)| d \tau
$$

を用いてパラメータ化した（以下，自己相関パラ メー夕). 自己相関パラメー夕は, 自己相関関数 の時間差にともなう減衰の程度を表しており，そ の值が大きい場合は減衰が小さく，つまり包絡線 が周期的，あるいは持続的な波形であることを意 味する，ただし，周期的と持続的の区別は自己相 関関数波形の視察によらなければならない。

同様に，式 $(4)$ の相互相関関数 $C C （ \tau)$ を包 絡線の全組み合わせについて求めた.

$$
C C(\tau)=\frac{1}{T} \int_{-T / 2}^{T / 2} x(t) y(t+\tau) d t
$$

相互相関関数を求めることにより，各包絡線波 形間の相互相関の最大值（以下，相互相関係数） と相互相関が最大となる時間差 $\tau$ をパラメータと して抽出した。

相互相関関数は各包絡線間の関係を明らかにす るものであるが，運動の局面に対する情報が明確 ではない。そこで，本研究では，リリース時刻に 対する相対的な時間差を調べるために，リリース 時刻でピークとなるデル夕関数 $\delta(t)$ を用いて, リリースとの関係についても調べた.デル夕関数

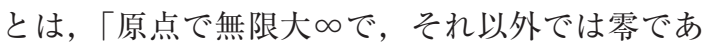
り，原点を含む区間での積分值は有限 $(=1) 」$

$$
\int_{-\infty}^{\infty} \delta\left(t-t_{0}\right) d t=1
$$

となる特異な性質を持つ超関数である（日野, 1977). そして，この超関数は普通の単純な関数 (原形）の極限形と考えることができるため，そ の原形として次式のガウス型の関数を導入した。

$$
\delta\left(t-t_{0}\right)=\frac{a}{\sqrt{\pi}} \exp \left[-a^{2}\left(t-t_{0}\right)^{2}\right]
$$

ただし，

$$
a>0
$$

である。また， $a$ がめの極限で $\delta\left(t-t_{0}\right)$ は $\infty$ と なり，裙幅は 0 に近づく。ここでは $a=0.2 ， t_{0}$ を リリース時刻とした。なお，相関の計算は FFT により行った。

\section{5. 投球動作の期分け}

図 1 に，分析結果および考察の理解を助けるた めに，投球動作の一般的な期分けを示す。ここで は，投球動作全体を六つの局面に分けた（Fleisig et al., 1996).これら局面の時間的目安を示すと， リリースを基準の $0 \mathrm{~ms}$ として， ワインドアップ 期は $-1000--900 \mathrm{~ms}$ から，ストライド期は - 500ms 程度から，コッキング期は- 200 $-150 \mathrm{~ms}$ から, 加速期は $-100 \mathrm{~ms}--50 \mathrm{~ms}$ から，

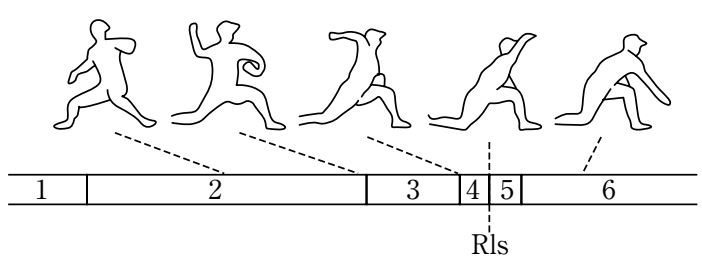

図1 投球動作の一般的な期分け例. 1. 構えから踏み出 し脚の振り上げまでをワインドアップ期，2. 振り上げ た踏み出し脚が投球方向に運動し始めから, 踏み出し足 が接地するまでをストライド期，3. 投球側の肩関節が 最大外旋するまでをコッキング期， 4 . 最大外旋からボ ールリリース Rlsまでを加速期，5. ボールリリース後， 投球側の肩関節が最大内旋するまでを減速期，6. 減速 期以後をフォロースルー期とする（Fleisig et al., 1996）. 
減速期は $+50 \mathrm{~ms}$ - + 100ms，そしてフォロース ルー期はそれ以降となる。

\section{III 結果}

\section{1. 投球スピードおよび筋活動のセット間の ばらつき}

投球試技は全力で行わせたが，8チャンネルの 表面電極を被験筋に貼付することにより，両被験 者ともに，貼付しない場合に比べ平均で 1 割程度 のスピード低下が認められた。ただし，セット内 での投球スピードのばらつき幅は，被験者 $\mathrm{A} に$

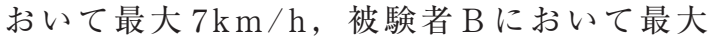
$4 \mathrm{~km} / \mathrm{h}$ で，セット間の投球スピードに差は認め られなかった。実験中の投球スピードは，全試技 平均で被験者 $\mathrm{A}$ は $117.6 \pm 2.7 \mathrm{~km} / \mathrm{h}$, 被験者 $\mathrm{B}$ は $122.4 \pm 1.7 \mathrm{~km} / \mathrm{h}$ であった。

また，全てのセットで記録した上腕二頭筋長頭 の活動夕イミングの傾向は，全ての試技において
同様で安定していたそして，それら全組み合わ せの相互相関係数の平均は $0.86 \pm 0.04$, 時間差は $4.9 \pm 13.0 \mathrm{~ms}$ であった。

\section{2. 表面筋電図生波形および包絡線}

被験者 $\mathrm{A} ， \mathrm{~B}$ の 25 部位から導出した表面筋電 図生波形を，リリース時刻を基準（0ms）とした リリース前 $1000 \mathrm{~ms}$ （以下，-1000ms）ーリリー ス後 $500 \mathrm{~ms}$ (以下, $+500 \mathrm{~ms}$ ) について図 2 に示 す。被験者 $\mathrm{A} ， \mathrm{~B}$ ともに投球スピード $120 \mathrm{~km} / \mathrm{h}$ 前後で投球した時のデータである。図 1 で説明し たように， - 1000msは，ワインドアップ期に相 当し， +500msはフォロースルーが完全に終了 した時期で，二人の被験者も同様であることがビ デオ画像から確認できた。

眓 3 に， - 300ms から+200ms までの筋電図 を全波整流し，MVCで基準化した包絡線波形を 示す。この期間は，投球動作の局面では，ストラ イド期の中程からフォロースルーの終了期に相当
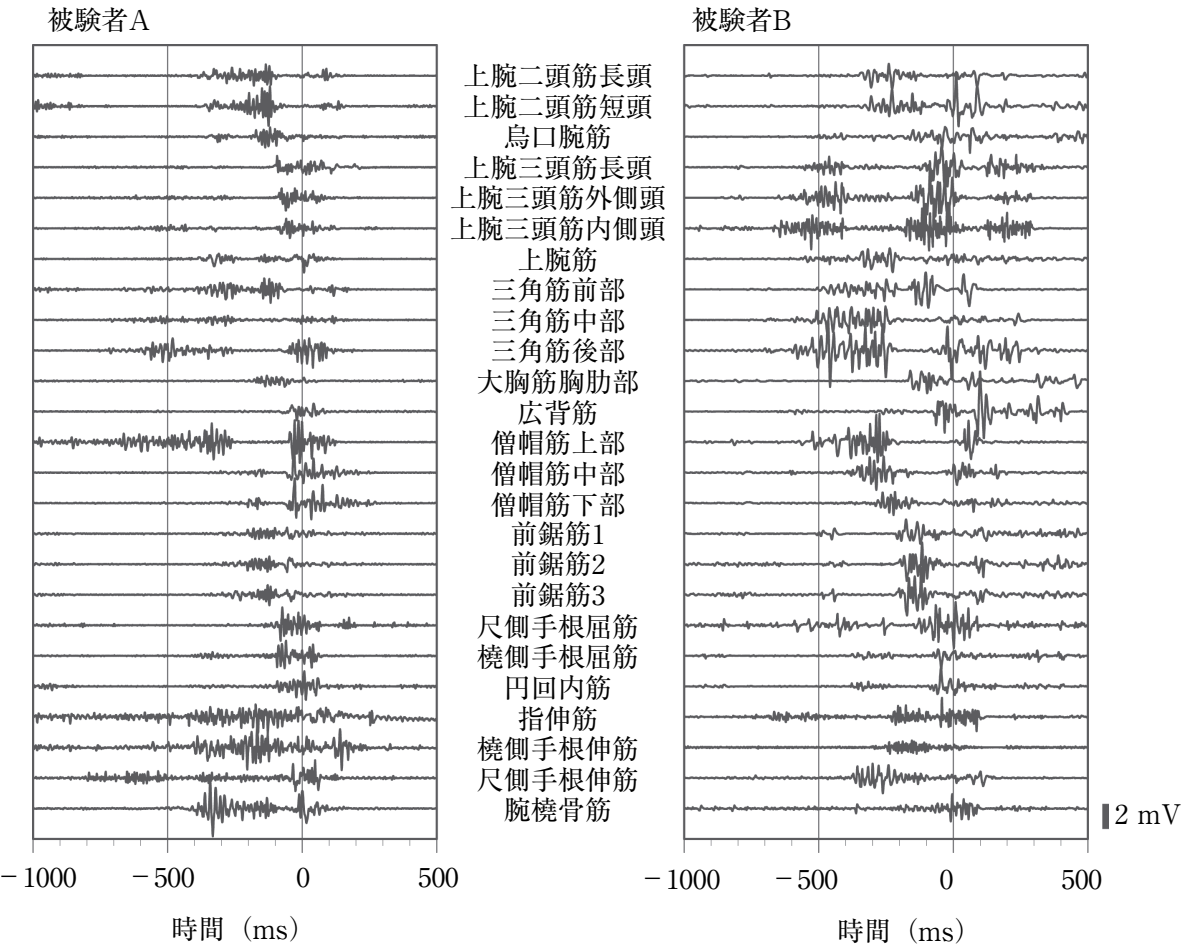

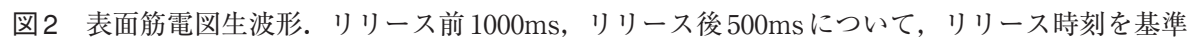
（0ms）にして 4 セット分のデータをまとめた一例. 
被験者A

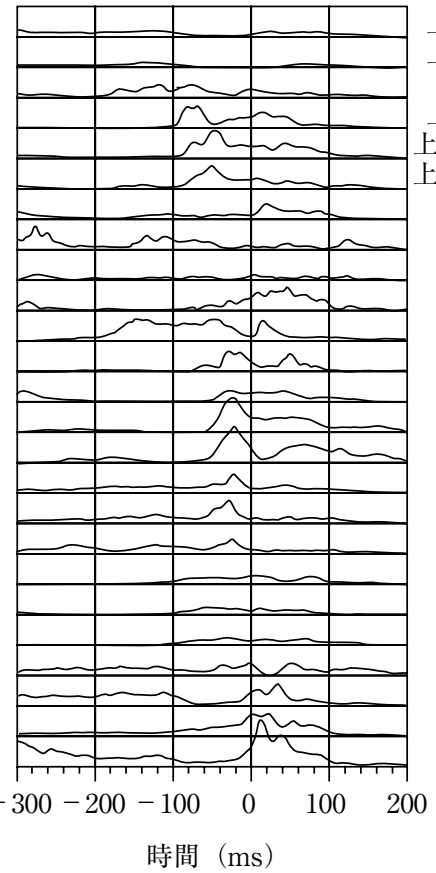

被験者 $\mathrm{B}$

上腕二頭筋長頭 上腕二頭筋短頭 烏口腕筋 上腕三頭筋長頭 腕三頭筋外側頭 腕三頭筋内側頭 上腕筋

三角筋前部 三角筋中部

三角筋後部 大胸筋胸胁部 広背筋 僧帽筋上部 僧帽筋中部 僧帽筋下部 前鋸筋1 前鋸筋 2 前鋸筋 3 尺側手根屈筋 橈側手根屈筋 円回内筋 指伸筋 橈側手根伸筋 尺側手根伸筋 腕橈骨筋

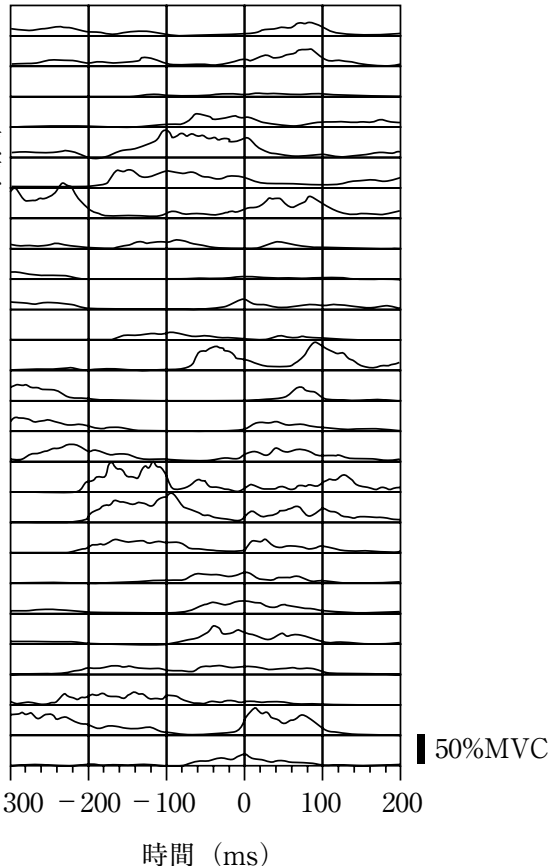

図 3 表面筋電図包絡線波形。リリース前 $300 \mathrm{~ms}$ ，リリース後 $200 \mathrm{~ms}$ について MVC 時の表面筋 電図包絡線平均值を基に基準化した。リリース時刻を基準（0ms）にして，4セット分のデー 夕をまとめた一例.

する.これら包絡線の視察から, 次のようなこと がいえる。

上腕二頭筋は $-300 \mathrm{~ms}$ 以前から $-100 \mathrm{~ms}$ まで 活動し，その後リリースまで活動を停止した。さ らに，リリースから+100ms 程度まで再び活動 が見られた。 上腕三頭筋は上腕二頭筋と相反的 に，-100msからリリースまで加速期を中心と して活動した。烏口腕筋は，上腕二頭筋と三頭筋 の中間的な活動様相を呈した。 上腕筋は上腕二頭 筋に近い活動様相を示したが加速期にも活動が見 られた。三角筋は， $-300 \mathrm{~ms}$ 以前にも持続的な 活動が見られるが，-200ms一フォロースルー では，前部と中部が先行し，後部が続いて活動開 始する傾向にあった。とくに後部はリリース直前 から+100msくらいまで活動した。大胸筋 は，-200msくらいから，+100msくらいまで

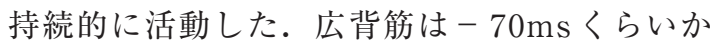
ら+100一+200msくらいまで活動した。僧帽筋 は上部, 中部, 下部の順で活動し, 一旦活動を停
止した後，被験者 $\mathrm{A}$ においてはー 50msくらいか ら，被験者 Bにおいてはリリース近辺から $+200 \mathrm{~ms}$ くらいまで活動した。前鋸筋はリリー ス前の活動が大きいものの，ほぼリリース前後の 400一 $500 \mathrm{~ms}$ にわたって持続的に活動していた。 そして，導出した三部位はほぼ同期していた。た だし，被験者 Aは活動ピークがー $50 \mathrm{~ms}$ あたり， 被験者Bはー200-ー100msであった. 前腕の屈 筋群は-100ms から+100ms の間活動していた。 それに対して伸筋群は屈筋群より早い時期から持 続的に活動する特徴が認められた。

\section{3. 自己相関関数, 相互相関関数}

筋活動の持続性と, 部位間の活動関係を定量的 に捉えるために，25個の包絡線波形の自己相関 関数と相互相関関数を求めた。自己相関関数は 25 個，相互相関関数はリリースを表すデルタ関 数を含めた全ての組み合わせで 650 個（対称性を 考慮すると 325 個）となった。それぞれ自己相関 


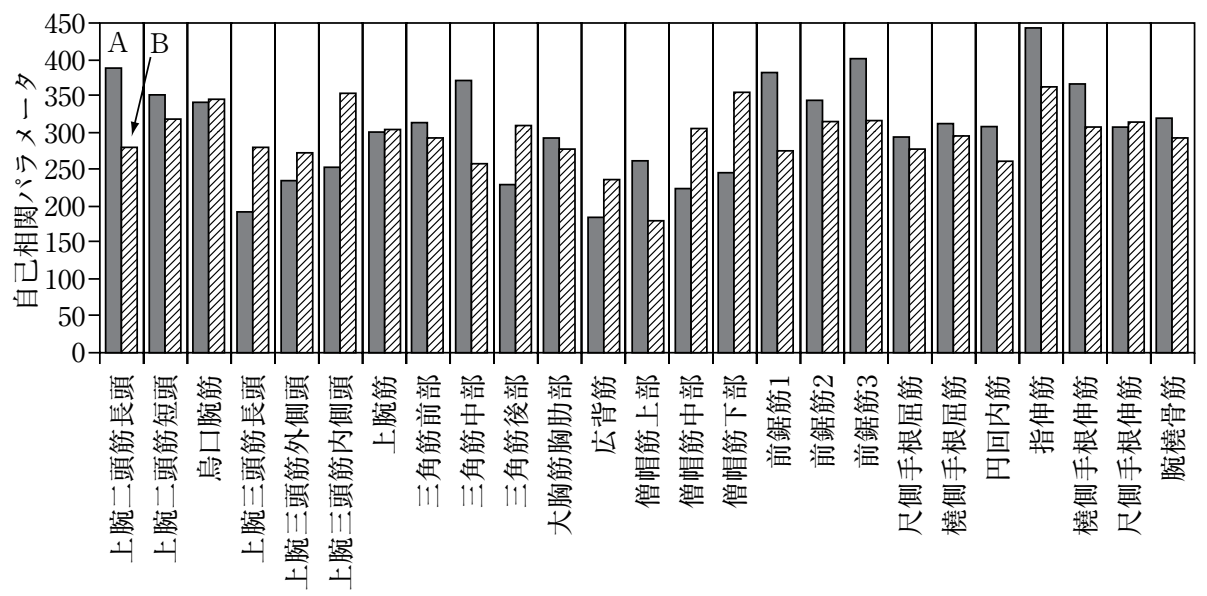

図4 自己相関パラメータ。リリース前 $300 \mathrm{~ms}$ からリリース後 $200 \mathrm{~ms}$ までの筋電図包絡線の自己 相関関数から式（3）を用いて求めた值.

被験者 $\mathrm{A}$

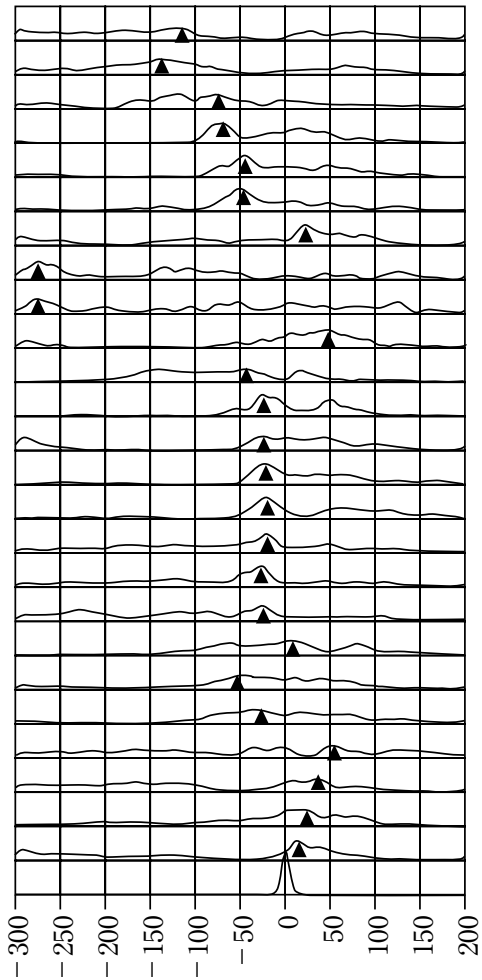

時間差 $(\mathrm{ms})$

\section{被験者B}

上腕二頭筋長頭 上腕二頭筋短頭 烏口腕筋

上腕三頭筋長頭 上腕三頭筋外側頭 上腕三頭筋内側頭 上腕筋

三角筋前部

三角筋中部

三角筋後部

大胸筋胸胁部

広背筋

僧帽筋上部

僧帽筋中部

僧帽筋下部

前鋸筋 1

前鋸筋 2

前鋸筋3

尺側手根屈筋

橈側手根屈筋

円回内筋

指伸筋

橈側手根伸筋

尺側手根伸筋

腕橈骨筋

リリース

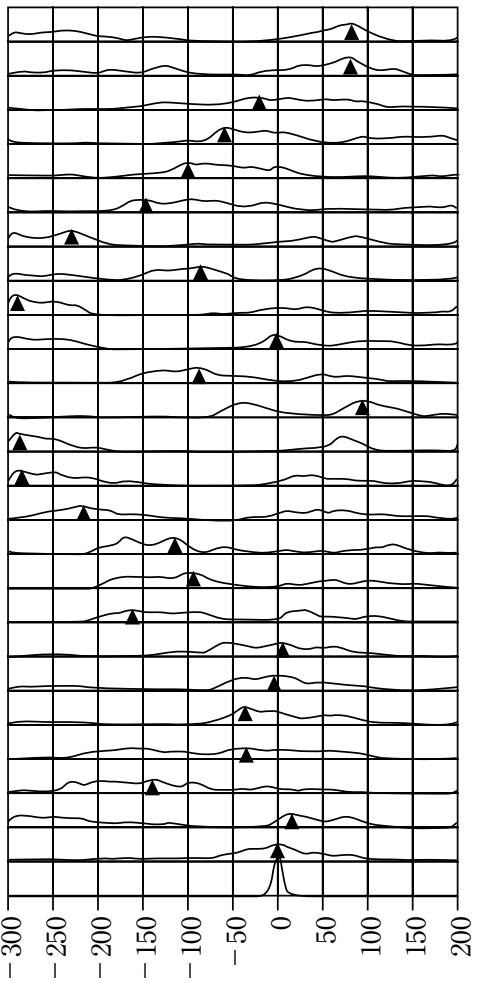

時間差 (ms)

図 525 部位の筋電困包絡線とデルタ関数との相互相関関数の一例. リリースを示すデルタ関数 (最下段) を基準に表面筋電図包絡線との相互相関関数を示している.デルタ関数については 自己相関関数となり，時間差 $0 \mathrm{~ms}$ で相関係数は 1.0 となる. している．負の時間差はリリースに先行することを意味する. 
関数から自己相関パラメータ，相互相関関数から 最大值である相互相関係数と最大值をとる時間差 が得られた。

図 4 に，被験者 $\mathrm{A} ， \mathrm{~B}$ の 25 部位における筋電図 包絡線の自己相関パラメータを示す. 被験者 $\mathrm{A}$ では，上腕三頭筋長頭と広背筋の值が小さく，指 伸筋の值が最も大きかった。被験者 Bでは，僧帽 筋上部と広背筋の值が小さく，A と同様に指伸筋 の值が大きかった，概ね，両者とも上腕三頭筋， 広背筋，僧帽筋上部の值が小さく，前鋸筋および 前腕筋群で大きかった。

図 5 に被験者 $\mathrm{A}$ と B について，包絡線とリリー ス時刻を示すデル夕関数との相互相関関数を示す (デル夕関数については自己相関関数となる).こ の場合，裾幅が短い（約 $20 \mathrm{~ms}$ ）デル夕関数と包 絡線とのたたみ达み演算となるため，得られる相 互相関波形は筋電図包絡線そのものに近い。図中
のムはデル夕関数との時間差を示しており，した がって，各部位における筋活動ピークのリリース 時刻に対するタイミングのズレを表している。そ して，負の時間差はリリース前，正の時間差はリ リース後を表している.

被験者 Aについては, 時間差の絶対值は 7一 $276 \mathrm{~ms}$ (平均 $61.6 \pm 71.2 \mathrm{~ms}$ ) で, 上腕二頭筋, 烏 口腕筋や三角筋を除いてほぼリリース近辺 $(-50$ 一 + 50ms $)$ に活動ピークが集中していた。 それに対し被験者 B は，時間差の絶対值が 1 -

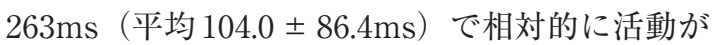
ばらついていた。

図 6 に各筋活動間の相互相関関数の一例とし て，腕橈骨筋活動と他の筋活動との相互相関を示 す（すべての筋部位をそれぞれ基準として相互相 関関数を計算すると，同様なグラフが 25 個でき る)。この場合，腕橈骨筋については自己相関関
被験者 $\mathrm{A}$

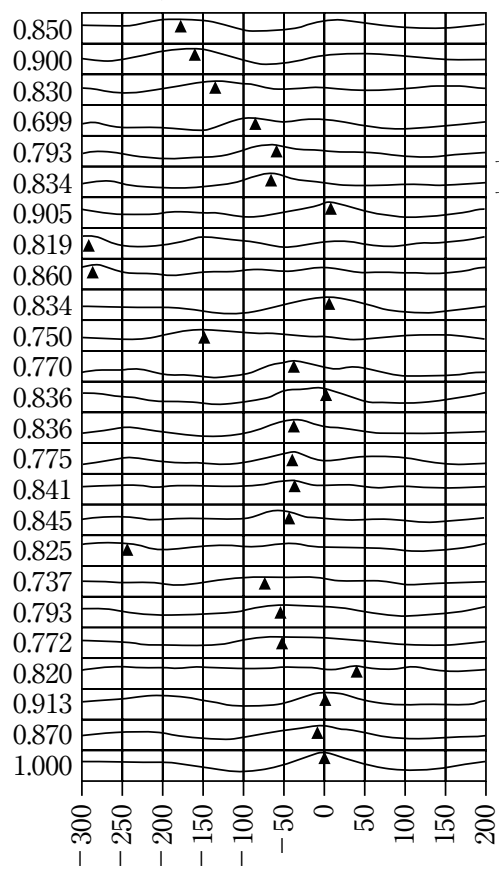

時間差 $(\mathrm{ms})$
被験者B

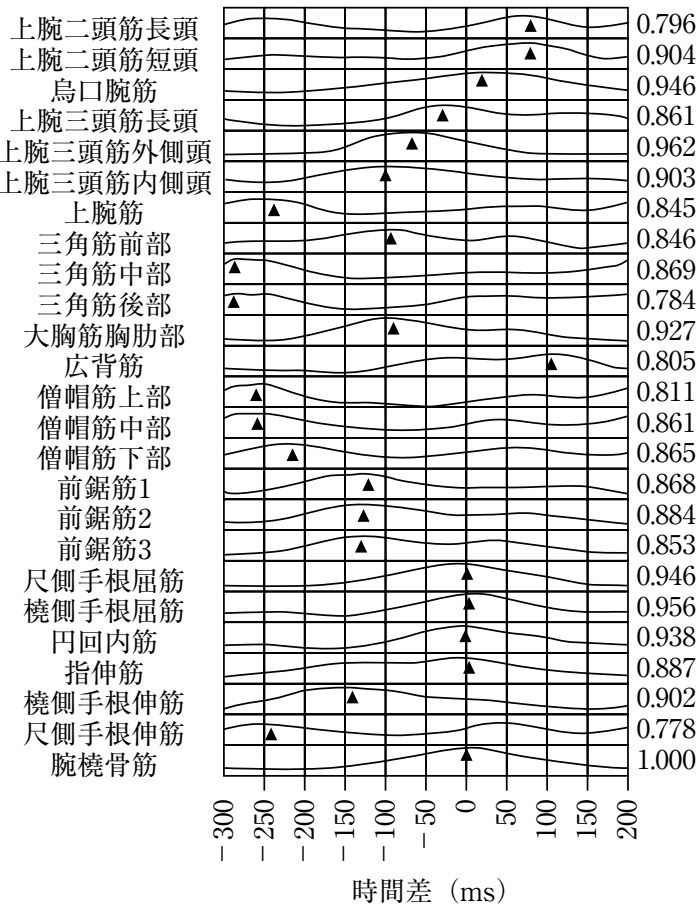

図6 筋電図包絡線間の相互相関関数の一例. 腕橈骨筋（最下段）を基準に他の部位の表面筋電図 包絡線との相関関数を示している. 腕橈骨筋は自己相関関数となり, 時間差 $0 \mathrm{~ms}$ で相関の最大值 は 1.0 となる. 、は相関が最大となる時間差を示している．負の時間差はリリースに先行するこ とを意味する．グラフ横（被験者 $\mathrm{A}$ は左，被験者 $\mathrm{B}$ は右）の数值は相関係数を示している. 


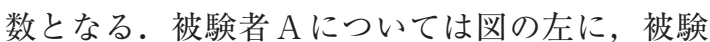
者Bについては図の右に相関係数を示している. 図中の $\Delta$ は腕橈骨筋との相関が最大となる時間差 （腕橈骨筋活動とのタイミングのズレ）を示して いる，そして，負の時間差は，その筋あるいは部 位が腕橈骨筋の活動に先行していることを示し, 正の時間差は遅れていることを示している。

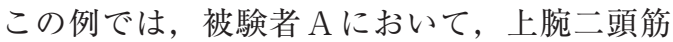
短頭，上腕筋，橈側手根伸筋との相関が比較的高 $<$ (0.9 以上), 上腕筋, 三角筋後部, 僧帽筋上部, 橈側手根伸筋，尺側手根伸筋が同期的に活動して いたことがわかる．また，被験者 Bでは，上腕二 頭筋短頭，烏口腕筋，上腕三頭筋外側頭，上腕三 頭筋内側頭，大胸筋，尺側手根屈筋，橈側手根屈 筋，円回内筋および橈側手根伸筋との相関が比較 的高く, 烏口腕筋, 尺側手根屈筋, 橈側手根屈筋, 円回内筋，指伸筋が同期的に活動していたことが わかる.

このような，各筋あるいは部位間の関係を，表 2（被験者 A）および表3（被験者 B）に相互相関 係数と時間差の行列として示す，相関係数行列は 対称行列，時間差行列は反対称行列となるため下 三角に相互相関係数，上三角に時間差（つまり， 時間差は上下で符号が逆転する，また，列方向と 行方向の間でも符号の意味は逆転する）を示して いる. そして， 0.9 以上の相関と $\pm 50 \mathrm{~ms}$ 以内の時 間差を網掛け表示している。さらに両条件を満た す組み合わせの要素を太線枠表示している，相互 相関係数は，被験者 $\mathrm{A}$ では $0.661-0.980$ (平均 0.844)，被験者 Bでは，0.649-0.966（平均 $0.841 ）$ であった。時間差は被験者 A では-249$+249 \mathrm{~ms}$ (平均 $-0.7 \mathrm{~ms}$ ), 被験者 Bでは $-249-$ $+247 \mathrm{~ms}$ (平均 $-1 \mathrm{~ms}$ ) であった.

相関が高く，時間差がとくに小さい（土10ms

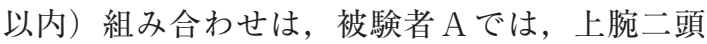
筋の長頭と短頭，上腕三頭筋の外側頭と内側頭， 僧帽筋の中部と下部，前鋸筋，尺側手根屈筋と橈 側手根屈筋および円回内筋，橈側手根伸筋と腕橈 骨筋などのように，同一筋内，あるいは同一筋群 内に多く見られた。それらは，行列（表2）内で は，対角に近いところに位置する組み合わせであ
る、また，上腕二頭筋長頭と橈側手根伸筋，烏口 腕筋と大胸筋，上腕筋と尺側手根伸筋，僧帽筋中 部と広背筋，上腕筋と腕橈骨筋，上腕三頭筋と広 背筋，僧帽筋および前腕屈筋群，尺側手根伸筋と 前腕屈筋群の組み合わせも相関が高く時間差が小 さかった。被験者 Bでは, 上腕二頭筋の長頭と短 頭, 上腕筋と尺側手根伸筋, 三角筋の中部と後部, 前鋸筋，僧帽筋中部と上腕筋と三角筋中部および 尺側手根伸筋，尺側手根屈筋と橈側手根屈筋と円 回内筋および腕橈骨筋の組み合わせにおいて，と くに相関が高く時間差が小さかった（土10ms 以 内). また，烏口腕筋と前腕筋群，大胸筋と前鋸 筋, 前腕屈筋群と腕橈骨筋の組み合わせにおいて も相関が高く時間差が小さかったが, 被験者 $\mathrm{A}$ に比してその組み合わせは少なかった。同期的に 働いた筋の組み合わせは，被験者 Bにおいて 92 であるのに対し，被験者 $\mathrm{A}$ では159で多かった。

\section{IV 考察}

大学野球選手 2 名を被験者とし, 投球時に上肢, 上肢带の 25 部位から表面筋電図を導出した。導 出した表面筋電図のうち, リリース時を基準に - 300ms から+200ms までの $500 \mathrm{~ms}$ を分析対象 とした。これらの区間における表面筋電図の包絡 線の視察に加え, 自己相関分析と相互相関分析を 行った。

\section{1. 投球時の筋活動について}

上腕二頭筋は，とくにコッキング期終盤におけ る肘関節の適度な屈曲位（トップポジション）の 形成に関与しており（Gowan et al., 1987)，投球 動作における「お膳立て」的な役割を担っている。 さらに，フォロースルー期において，上腕筋とと もに肘関節の屈曲による「後かたづけ」的な動作 に関与するだけでなく（Jobe et al.，1984； Gowan et al., 1987 ; Werner et al., 1993), 回 内した前腕を回外方向に解放するためにも活動し ていると考えられる (Fleisig et al., 1996).この ようなことから，上腕二頭筋は加速期からリリー ス近辺の動作には直接関与せず，その活動ピーク 


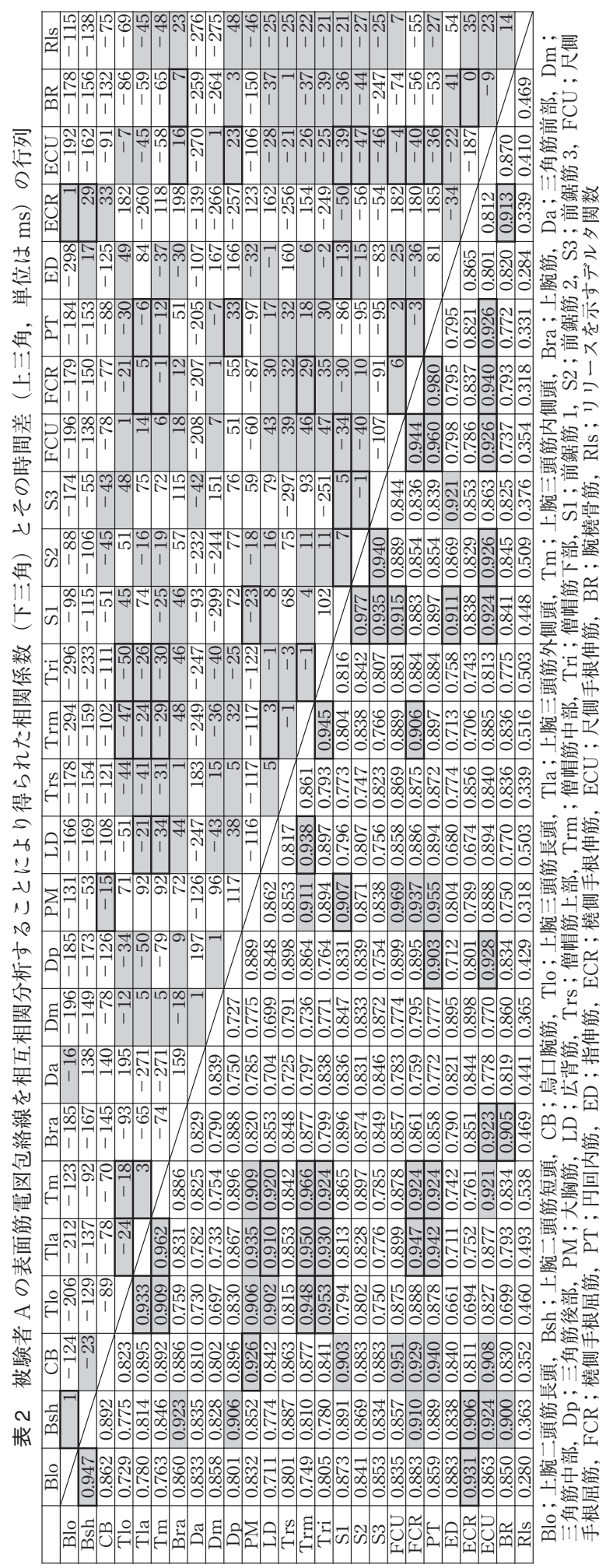

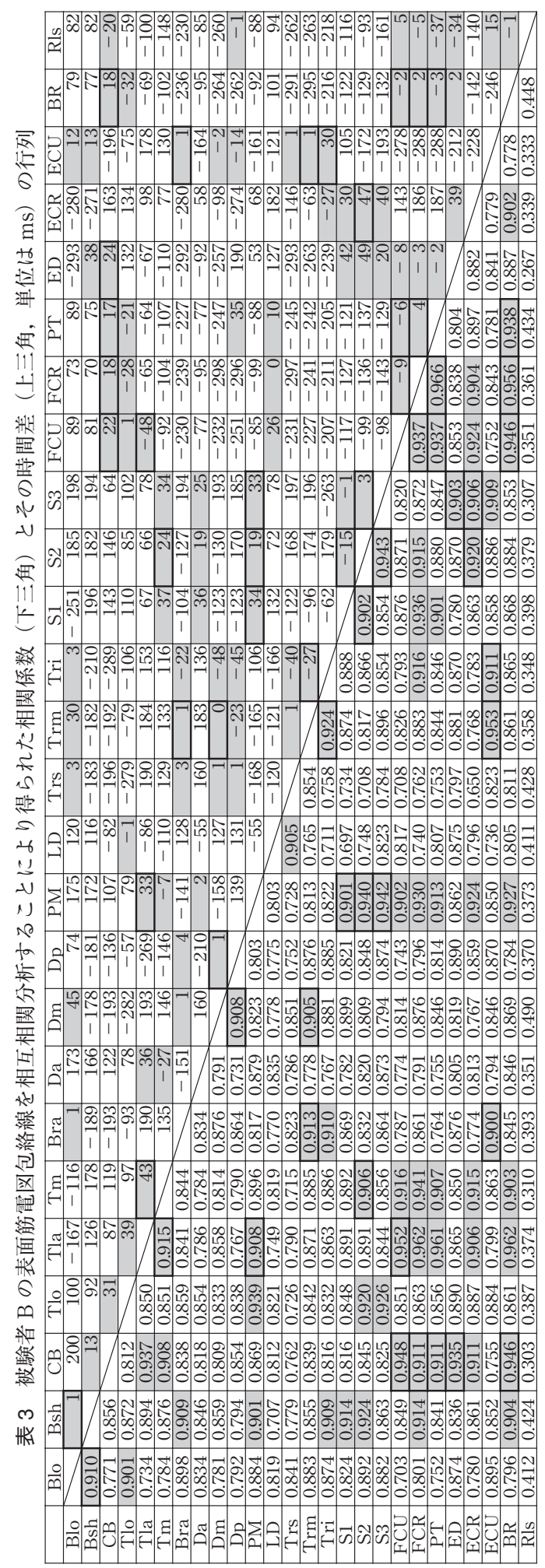


はコッキング期かフォロースルー期であり，他の 部位の活動ピークタイミングから外れる傾向にあ る(図5).

それに対し，上腕三頭筋はコッキング後期の後 期から加速期の时関節伸展に関与しており（豊島 ほか，1971; 風井ほか，1976; Hang，1983； Werner et al., 1993)，肘関節を伸展することに より投球スピード獲得に大きく貢献する筋である といえる (Jobe et al., 1984 ; Werner et al., 1993 ; Fleisig et al., 1995 ; 斎藤ほか, 2001a).

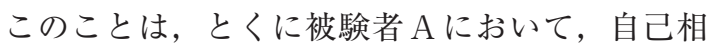
関パラメータの值が小さいことに現れている（図 4). 投球スピード増大の運動学的ポイントは，末 端（手，手指）のスピードを増大させることであ るが，駆動力を同一と仮定した場合，これは上肢 を動径とする回転半径を大きくすることによって 達成される。このためには, 体幹の運動を無視し て上肢に限定すると，肘の伸展度が大きな鍵を握 ることになる，また，肘の伸展は，上腕長軸周り の慣性モーメントを小さくし，肩関節内旋の運動 エネルギーを，できるだけ損失無く前腕回内運動 に伝えることにも貢献する（斎藤ほか，2001b）。 つまり，肩を中心と見た回転運動が作り出す末端 スピードに，前腕の回内による手および手指のス ピードを加えることで，ボールスピードがさらに 増大すると考えられる．加速期における上腕三頭 筋の活動は，このような運動の鍵になると考えら れる，ただし，体幹の投球方向への直線運動によ り生じる運動連鎖（Feltner，1989），あるいは回 旋運動と肩関節の内旋運動により生じるコリオリ 力 (大村, 2001) や遠心力によっても肘関節の伸 展が引き起こされるため上腕三頭筋活動が肘関節 伸展の全てではない.

上腕筋は，前述のように上腕二頭筋と協同して コッキング期，フォロースルー期に肘関節の屈曲 に関与している。これは，動作の上では，前述の ようにとくにフォロースルー期における前腕の回 外方向への運動と肘屈曲に両筋が同期活動したと 考えられる（Jobe et al., 1984）。一方で，上腕筋 は尺側手根伸筋（A では腕橈骨筋も）の活動様相 と類似しているが, 上腕筋は解剖学的に, 筋皮神
経だけでなく前腕伸筋群を支配する橈骨神経との 二重支配を受ける場合があり（山田・萬年，1985， pp. 396-397），この影響による可能性もある.

烏口腕筋は，コッキング期から加速期において 活動し, 主として肩関節の水平伸展 (上腕の内転)

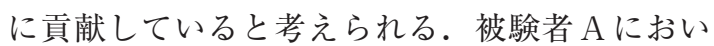
ては，大胸筋と活動様相が類似しており（表 2)， 主として肩の水平伸展に協同的に活動したと考え られる。一方, 被験者 Bでは, その活動強度は低 いものの, 活動タイミングがリリースと前腕筋群 に同期しており，被験者 $\mathrm{A} に$ に比して，水平伸展 で加速に貢献する度合いが大きいと考えられる。

三角筋は，肩関節の外転や屈曲・伸展に貢献す る筋であるが，投球中では肩関節の内外旋に関す る肢位の影響を受ける。つまり，コッキング期— 加速期一リリース一減速期一フォロースルー期に かけて，肩関節はほぼ外転位を保ったまま外旋位 から内旋位に移行するが，より外旋位にある場合 には三角筋前部が，そして，より内旋位にある場 合には三角筋後部が活動を強めるといえる (Fleisig et al., 1996)。このため, コッキング期 以降の活動パターンが概ね, 前, 中, 後部の順に なると考えられる。ただ，相互相関分析の時間 差からもわかるように, リリース近辺の動作に直 接関与しているのは三部位のうち後部である（表 2，3および図 5 ; DiGiovine et al., 1992). 後部 は，リリースやフォロースルーにおける肢位の関 係上，過度の内旋に抗する働きや，上腕骨頭を肩 関節内で安定させるローテーターカフと協㗢する ためと考えられる（Jobe et al., 1983）.

広背筋と大胸筋は, 互いに対称, 類似の関係に あり（山田・萬年， 1985, pp. 227-229), ともに 肩関節の内転，内旋に関与する（Jobe et al., 1984 ; Glowsman et al., 1988). しかし, 投球動 作中においては上肢に生じる遠心方向の力に抗す るようにも働いているといえる。前述のように， 投球中の上肢を,肩を中心とした動径と見たとき， とくに手首の位置では大きな遠心方向の加速度が 生じる，斎藤ほか (2002) によると, 手首で計測 した遠心加速度は - 100-+50ms の区間で増大 し, その大きさは $1000 \mathrm{~m} / \mathrm{s}^{2}$ にも達する場合があ 
る。このような大きな遠心加速度に拮抗して，上 腕骨頭と肩甲骨関節窩がつくる肩関節を安定化す るためには広背筋と大胸筋の活動は必須であり (Jobe et al., 1984 ; Glowsman et al., 1988)，同 時に前述のような三角筋後部の活動と協働してい る可能性がある。とくに広背筋の活動は, 主とし て加速期一フォロースルー期の短期間に限られる ことが，自己相関パラメータの相対的な小ささに 表れたといえる（図4）。

僧帽筋と前鋸筋は協働して肩甲骨の動きを制御 しており（山田・萬年，1985，pp. 223-225），そ れらの筋活動は，投球動作中の肩甲骨の動きも反 映している (Glousman et al., 1988 ; Fleisig et al.，1996)。被験者 Aにおいて両筋はほぼ同期的 に活動しているが，被験者Bにおいては僧帽筋が 先行し，前鋸筋はそれに続いて活動している。被 験者 $\mathrm{A}$ においては，- $50 \mathrm{~ms}$ ーリリースにおいて 僧帽筋の上部，中部，下部および前鋸筋が同期し たことから，加速期において肩甲骨を上方回旋さ せた状態で固定する働きが生じたと考えられる。 一方，被験者Bにおいては，僧帽筋と前鋸筋の活 動に時間的なズレがあり（表 3 および図 5), 加速 期においてはそれらの活動は比較的弱く，被験者 Aに比べ肩甲骨を固定するような㗢きは弱かった と考えられる，前述のように，動径としてみた上 肢の回転半径を大きくしてスピード増大を図るた めには，肩甲骨が外転した方が有利である。この 意味においては，加速期において強い筋活動のな かった被験者 $\mathrm{B} の$ 方が有利なのかもしれない。し かし，前鋸筋は肩甲骨の動きを制御することで肩 甲上腕関節を安定化させる機能も果たしており， 加速期前後で活動することは障害防止にも役立っ ている (Bradley and Tibone, 1991)。この意味 においては，被験者 $\mathrm{A} の$ 筋活動の方がより好ま しいのではないかと考えられる。

前腕の筋群は，ボールを手指で支持すること， リリース時に投球方向に対する指や手および手首 の姿勢を安定化させること，ボールに与えるスピ ンの量や質を調節すること等に関与している（斎 藤ほか，2001a）。そして，ボールを握る役目は手 内筋とともに指の屈筋群（浅指屈筋，深指屈筋）
が担うことになるが，これら屈筋の活動は同時に 手首の屈曲にも働くため, これを相殺するために， 伸筋群が，ストライド期あたりから持続的に働く ことになる（Sisto et al.，1987）。また，伸筋群 は屈筋群に比べるとその筋量は貧弱であり（山 田・萬年，1985，pp. 428-430)，屈筋に拮抗する ためには，伸筋の活動をより強める必要がある. このことが，両被験者において，指伸筋活動の自 己相関パラメータが大きくなった原因と考えられ る（図4）。一方で，活動のピークでみると，被 験者 $\mathrm{A}, \mathrm{B}$ ともにリリース近辺で同期的であるこ とから，手首の運動のリリースへの貢献度の高さ が伺える．また，前腕の筋活動や運動を総合的に 判断すると，リリースとは「手首の屈曲」という より，むしろ手首の関節を固くして，ボールを手 指で「ひっかく」ような運動であるといえる.

\section{2. 相関分析の意義および今後の課題}

自己相関関数，相互相関関数ともに時間差の関 数である. 自己相関関数は波形の周期性や持続性 を表すもので，時間差 0 で相関係数が 1 となる. 一方, 相互相関関数は二つの活動間の位相差や活 動の類似度を表すもので，活動のズレが時間差と して，そして活動様相の類似度が相関係数として 定量化される. 本研究の場合, 分析対象の筋電図 が包絡線波形（非負）であったため，これら相関 係数は $0.0-1.0$ の值となった。

自己相関関数から求めた自己相関パラメータ は，時間差にともなう自己相関関数の減衰傾向を 表す。そして，この減衰傾向は，筋活動の持続性 や周期性を反映している。とくに本研究の場合, 持続的に活動した筋の自己相関関数は，時間差に ともなう減衰傾向が小さく自己相関パラメー夕は 大きくなる。それに対し，活動がある局面に限定 されている筋では，その自己相関パラメータは小 さくなる，本研究では，加速期に集中的に活動す る広背筋の自己相関パラメータが小さかったのに 対し，ボール保持に関わる前腕伸筋群の值が大き く,その活動傾向が定量的に表現できたといえる. ただし，本研究の場合， - 300ms-+200msの $500 \mathrm{~ms}$ 間を分析対象としており，対象区間長を変 
えることにより，自己相関パラメータの相対的大 小関係が変化する可能性はある。

多部位から筋電図を導出する場合，被験筋選択 の妥当性の問題は依然として残るものの，部位間 の活動関係を定量化するのに相互相関分析法は適 しているといえる. 例えば, リリース時刻を表し たデル夕関数との相互相関を求めることで，活動 ピークとリリース時刻との関係を明確に表すこと ができた。この意味で，図 5 のような相互相関関 数は活動パターンということができる。つまり, 図 5 の相関関数は,リリース時刻を中心にして図 3 の包絡線を規格化した波形であり，包絡線以上 の情報を含んでいないばかりか，\% $\mathrm{MVC}$ 等の強 度の情報が失われてしまう。しかし，規格化によ り強度情報を隠蔽することで，活動の関係性を重 視した活動パターンの比較が容易になる。これに より，筋電図データから動作を再現することが困 難であるという問題が解決されるわけではない が，筋活動の配列に焦点を当てやすいという点で 有効である。

また，ガウス型デル夕関数のパラメータである $a$ や $t_{0}$ を変えることで，任意の分析が可能となる 利点もある，たたみ达み演算は，一種のフィル夕 リングとして機能するため，例えば， $a$ を大きく した裙幅の大きいガウス型関数を用いると，たた み込み演算の結果，より滑らかな相互相関波形が 得られ筋活動を二值的に粗視化することができ る.一方，本研究では $t_{0}$ をリリース時刻としたが， 例えば，最大外旋時とすることで最大外旋時刻か ら見た筋活動タイミングを明確に定量表示するこ とができる.

一方，相互相関係数の大小は，あくまでも活動 波形の類似度である。したがって，パフォーマン スとの関連は明確ではないものの, 時間差が小さ く, 相関が高い場合は, 同期的であるだけでなく, それぞれの局面における運動への協働的な貢献で あることを示唆しているといえる，また，本研究 では言及しなかったが，類似の機能を持つ筋群内 の活動分析，同一被験者内の異なる試技間におけ る同一筋部位の活動比較，異なる被験者間におけ る同一筋部位の活動比較などにおいても本手法は
有効であるといえる。しかしながら，相互相関関 数は二部位間の活動関係の情報に過ぎず，パフォ ーマンスの全般にわたって，対象とした部位全て の活動の関係性を述べるものではない。この点に おいて，今後，新たな分析法が期待される.

また，図 $5 ， 6$ や表 $2 ， 3$ において被験者 $\mathrm{A}, \mathrm{B}$ の投球における筋活動の違いが明らかであるが, どちらが投球パフォーマンス上，より適切な，よ り優れた筋活動であるか，あるいはより適切な筋 活動が他にあるのかは現時点では明確にできな い. 優れたパフォーマンスとはどういうことか, そして，それは普遍的なものなのか，あるいは特 殊性があるものなのか，これらに関しては将来に おける大きな検討課題であるといえる.

\section{V ま と め}

野球投球動作中の上肢・上肢帯筋活動を分析す るために，表面筋電図を計測し，視察による定性 的分析に加えて相関分析を行った. 表面筋電図は, 2 名の大学野球選手を被験者として, 上肢・上肢 带の 16 筋 25 部位から導出した。計測は，8チャ ンネルのテレメータ式筋電計を用い，4セットに 分けて行った。表面筋電図包絡線の視察，および 自己相関分析法よび相互相関分析を行った結果, 筋活動の持続性，タイミングや類似性を定量的に 捉えることができた。個々の筋については以下の 通りである。

1. 上腕二頭筋，上腕筋は主にストライド期— コッキング期およびフォロースルー期において活 動した。これら筋活動は, 加速・減速のための準 備，補助的な作用と考えられた。

2. 上腕三頭筋は加速期を中心に活動し，肘関 節の伸展により投球スピード増大に貢献している と考えられた。

3. 烏口腕筋, 大胸筋はコッキングからリリー スに向けての肩関節の水平伸展に関与すると考え られた。

4. 三角筋は，リリースにかけて前部，中部， 後部という順で活動する傾向にあり，とくに，リ リース近辺では後部の活動が主であった。 
5. 広背筋は, 加速期に集中して活動し, 持続 時間が短かった。これは，リリース近辺で肩関節 の内旋や遠心加速度に抗する働きが主であるため と考えられた。

6. 僧帽筋と前鋸筋は，加速期において同期的 に働く例と加速期以前に非同期的に働く例が見ら れた。これらは，投球中における肩甲骨の動きの 制御方法が異なるためと考えられた。

7. 前腕筋群は, 活動のピークが他の筋に比し てリリース近辺に集中する傾向にあったが，伸筋 群の方がより持続的に働く傾向が見られた。

8. これら筋の全体的な活動を見ると, 被験者 2 名のうち，一方はリリースを中心として同期的 に働く傾向に，他方は非同期的に働く傾向にあっ た。

\section{文献}

Barrentine, S.W., Matsuo, T., Escamilla, R.F., Fleisig, G.S., and Andrews, J.R. (1998) Kinematic analysis of the wrist and forearm during baseball pitching. J. Appl. Biomech., 14: 24-39.

Bradley, J.P. and Tibone, J.E. (1991) Electromyographic analysis of muscle action about the shoulder. Clin. Sports Med., 10: 789-805.

DiGiovine, N.M., Jobe, F.W., Pink, M., and Perry, J. (1992) An electromyographic analysis of the upper extremity in pitching. J. Shoulder Elbow Surg., 1: $15-25$.

Feltner, M.E. (1989) Three-dimensional interactions in a two-segment kinetic chain. Part II: Application to the throwing arm in baseball pitching. Int. J. Sport Biomech., 5: 420-450.

Fleisig, G.S., Barrentine, S.W., Escamilla, R.F., and Andrews, J.R. (1996) Biomechanics of overhand throwing with implications for injuries. Sports Medicine, 21: $421-437$.

Glousman, R., Jobe, F., Tibone, J., Moynes, D., Antonelli ,D., and Perry, J. (1988) Dynamic electromyographic analysis of the throwing shoulder with glenohumeral instability. J. Bone Joint Surg., 70A: $220-226$.

Gowan, I.D., Jobe, F.W., Tibone, J.E., Perry, J., and
Moynes, D.R. (1987) A comparative electromyographic analysis of the shoulder during pitching. Professional versus amateur pitchers. Am. J. Sport Med., 15: 586-590.

Hang, Y. (1983) Little league elbow: A clinical and biomechanical study. Biomechanics VIII-A, Human Kinetic Pub. Inc.: Illinois, pp. 70-85.

日野幹雄（1977）スペクトル解析。朝倉書店：東京, pp. $25^{-76 .}$

平野裕一・青木秀憲（1998）投球速度漸増にともな う投球腕上肢および上肢帯筋の活動の変化. 体育 科学, $26: 11-18$.

Jobe, F.W., Tibone, J.E., Perry, J., and Moynes, D. (1983) An EMG analysis of the shoulder in throwing and pitching. A preliminary report. Am. J. Sport Med., 11: 3-5.

Jobe, F.W., Moynes, D.R., Tibone, J.E., and Perry, J. (1984) An EMG analysis of the shoulder in pitching. A second report. Am. J. Sport Med., 12: 218220 .

風井訫恭 - 熊本水頼 - 岡本 勉 - 山下謙智 - 後藤幸 弘・丸山宣武（1976）野球の投動作（オーバーハ ンドスロー）における上肢・上肢帯筋群の作用機 序. 体育学研究, $21 ： 137-144$.

Matsuo, T., Matsumoto, T., Mochizuki, Y., Takada, Y., and Saitou, K. (2002) Optimal shoulder abduction angles during baseball pitching from maximal wrist velocity and minimal kinetics viewpoints. J. Appl. Biomech., 18: 306-320.

宮西智久 - 藤井範久 - 阿江通良 - 功力靖雄 - 岡田守 彦（1996）野球の投球動作におけるボール速度に 対する体幹および投球腕の貢献度に関する 3 次元的 研究. 体育学研究, 41：23-37.

大村皓一（2001）メジャーリーグVS. 日本野球. 講 談社現代新書：東京, pp. 58-75.

Saitou, K., Masuda, T., Michikami, D., Kojima, R., and Okada, M. (2000) Innervation zones of the upper and lower limb muscles estimated by using multichannel surface EMG. J. Human Ergol., 29: 35-52. 斎藤健治・仰木裕嗣・市川 浩 - 井上伸一 - 松尾知 之・足立和隆・宮地 力・高井省三（2001a）投球 スピード漸増および球種の違いによる上肢筋活動 の変化. 筑波大学体育科学系紀要, $24: 79-88$. 斎藤健治・仰木裕嗣・市川浩 - 山岸正克 - 宮地 
力・高井省三 (2001b) 投球時に手首で測定した加 速度波形のパターン分類. いばらき健康・スポー ツ科学, $19: 13-26$.

斎藤健治 ·仰木裕嗣 - 井上伸一 - 市川 浩 - 山岸正 克・宮地 力・高井省三 (2002) 手首で計測した 加速度による投球スピードの推定. 体育学研究, 47 : 41-51.

Sakurai, S., Ikegami, Y., Okamoto, A., Yabe, K., and Toyoshima, S. (1993) A three-dimensional cinematographic analysis of upper limb movement during fastball and curveball baseball pitches. J Appl. Biomech., 9: 47-65.

Sisto, D.J., Jobe, F.W., Moynes, D.R., and Antonelli, D.J. (1987) An electromyographic analysis of the elbow in pitching. Am. J. Sport Med., 15: 260-263.
高橋佳三・阿江通良・藤井範久 - 島田一志 - 尾崎哲 郎（2000）野球のピッチングにおける手および指 の動きとボール速度増加の関係. バイオメカニク ス研究, 4 : 116-124.

豊島進太郎・松井秀治 - 宮下充正 (1971) 投球動作 における上肢筋の筋電図学的研究. 体育学研究, $15: 103-109$.

Werner, S.L., Fleisig, G.S., Dillman, C.J., and Andrews, J.R. (1993) Biomechanics of the elbow during baseball pitching. J. Orthop. Sport. Phys. Therapy, 17: 274-278.

山田致知・萬年 甫 (1985) 実習解剖学. 南江堂 : 東京.

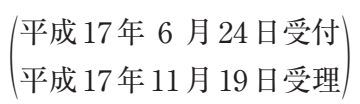

